\title{
Effect of cadmium supply levels to cadmium accumulation by Salix
}

\author{
T. Ling; *R. Jun; Y. Fangke
}

\author{
${ }^{1}$ School of Environmental and Municipal Engineering, Institute of Environmental Ecology, Lanzhou Jiaotong \\ University, Lanzhou, China and Engineering Research Center for Cold and Arid Regions, Water Resource \\ Comprehensive Utilization, Ministry of Education, Lanzhou, China
}

Received 6 July 2010; $\quad$ revised 22 October 2010; $\quad$ accepted 24 March 2011; $\quad$ available online 1 June 2011

\begin{abstract}
The present investigation reports the results of the cadmium accumulated by Salix matsudana, S. alba var. Tristis and S. babylonica in a pot experiment at six different levels of cadmium supply (0, 0.5, 2, 6, 25, 60 mg/kg). All tested Salix species showed the different abilities to remove cadmium, which depend on species and concentrations level. Cadmium accumulated by the leaves, twigs and roots linearly increased with increasing cadmium supply levels. The higher concentration cadmium treatments significantly promoted the cadmium accumulation. S. matsudana always performed the stronger ability of cadmium accumulation under different cadmium supply treatments, while $S$. alba var. Tristis and S. babylonica had the poorer accumulation ability. Cadmium in soil was more intensively absorbed in the leaves and twigs for all three Salix species, was not retained in roots and was transferred to aboveground plant tissues. The results indicated that Salix has an excellent potential for cadmium phytoremediation because of its high accumulation ability.
\end{abstract}

Keywords: Heavy metal; Phytoremediation; Plant; Uptake

\section{INTRODUCTION}

Industrial process, agricultural productions, mining and other human activities have resulted in considerable contamination of soils with heavy metals (Goyal et al., 2008; Atafar et al., 2010). Soils polluted with metals may threaten ecosystems and human health (Pulford and Watson, 2003; Dobaradaran et al., 2008a; b). Traditional remediation technologies of soils contaminated with toxic metals are generally too costly, and often result in decoration of soil properties (Meers et al., 2004). The potential use of trees as a suitable vegetation cover for heavy metalcontaminated land, with their lower cost and environmental friendly nature, has attracted increasing attentions (Lee et al., 2007; Perez-Sirvent et al., 2008). Most of studies on phytoremediation have mainly focused on metal hyperaccumulating plants (Blaylock and Huang, 2000; Nouri et al., 2009). Hyperaccumulators can accumulate several hundreds fold certain metals comparing normal plant species, with no adverse effects on their growth (Reeves and Baker, 2000; Lasat, 2002). However, hyperaccumulators are usually small biomasses with low growing rates

ه *Corresponding Author Email: renjun@mail.lzjtu.cn Tel: +860931 4938 177; Fax: +860931 4956017 and no economic value. Trees have been suggested as a low-cost, sustainable and ecologically sound solution to the remediation of heavy metalcontaminated land (Dickinson, 2000), especially when it is uneconomic to use other treatment or there is no time pressure on the reuse of the land. Benefits can arise mainly from stabilization of the soil or waste, although in some cases phytoextraction may be sufficient to provide cleanup of the soil. Therefore, some Salix species might be an interesting alternative with their high biomass production and fast-growing advantage (Greger and Landdberg, 1999; Pulford and Watson, 2003; Maria et al., 2007; Zacchini et al., 2009). Salix plant species that produce high biomass can be proposed for use in phytoremediation technology.

Among the heavy metals, $\mathrm{Cd}$ is of special concern due to its relatively high mobility in soils and potential toxicity to biota at low concentrations. Although Cd is naturally present in soil at trace amounts, high levels of Cd have been reported in some environment (Das et al., 1997). Zea mays L. seedlings accumulated more copper in roots but greater contents of zinc in their shoots (Mahmood et al., 2005 ). Different species show different levels of tolerance to $\mathrm{Cr}^{2+}$ pollution 
(Shrestha et al., 2007; Nabulo et al., 2008; Jun et al., 2009; Ayari et al., 2010).

Some heavy-metal contaminated soils may be cleaned up by growing plants which accumulate the pollutants, then harvesting the plants and disposing of them in a 'safe area'. This kind of technology, known as "phytoremediation”, represents a harmless and low cost technique, lacking of distinctive side effects (Cunningham and Owen, 1996; Ledin, 1998). Triticum aestivum, Eruca sativa and Dumasia villosa seedling length decreased in the high concentration of chromium treatment (Jamal et al., 2006; Perez-Sirvent et al., 2008). The ideal plants species to remediate a heavy metal-contaminated soil would be a high biomass producing species that can both tolerate and accumulate the contaminants of interest. For the purpose of phytoremediation, Punshon and Dickinson (1996) suggested that the following characteristics were beneficial for woody plants:

1) ability to grow on nutrient-poor soil;

2) deep root system;

3) fast rate of grow;

4) metal-resistance trait

Greger and Landberg (1999) discussed the potential of Salix for the decontamination of Cd-contaminated soils, reporting that 12 years of growth would be required to remove the $\mathrm{Cd}$ accumulated in Swedish soils during the last century.

Two possible strategies have been proposed for the use of Salix for phytoremediation. One is Salix that survive in contaminated soil with minimal uptake of metals into the aerial tissues would be most appropriate for use where distribution of heavy metals to the wider environment or transfer of metals into the food chain is to be avoided (Eriksson and Ledin, 1999; Vyslouzilova et al., 2003). Another one is Salix that accumulate relatively high amounts of metal are desirable if soil remediation is to be achieved by phytoextraction and tree harvesting.

The aim of the present study was to investigate species variation in Cd uptake and accumulation of three Salix species grown in soil containing a range of Cd concentrations. More specific, Cd concentration in different plant parts under a series of Cd contamination conditions was investigated. The experiment was carried in Institute of Environmental Ecology, Lanzhou Jiaotong University in April 2009.

\section{MATERIALSAND METHODS}

Cultivated experiments

In April 2009, the seedlings of three Salix ( $S$. matsudana, S. alba var. Tristis, S. babylonica) were planted in 180 10-litre plastic pots with $10 \mathrm{~kg}$ of sands. Six replications for each species were made in $6 \mathrm{Cd}$ treatments with $0,0.5,2,6,25,60 \mathrm{mg} / \mathrm{kg}$. The pots containing 3 seedlings were placed in a greenhouse. For 6 months of experiment, the night / daylight period of the greenhouse was $10 / 14 \mathrm{~h}$ and the temperature varied between 15.2 and $32.5^{\circ} \mathrm{C}$. The 180 pots were placed randomly in the greenhouse and watered three times a week with demineralized water in order to keep the sand's moisture content constant and care was taken to avoid leaching of water from the pots, a plastic tub was placed below each pot to collect the leachate. The collected leachate was again returned to the experiment pot. During the 6 months of the study, each pot was given about $600 \mathrm{~mm}$ of water.

Measurements of metal concentrations in plant samples

Aboveground biomass and root biomass were harvested after 6 months. Aboveground biomass was separated into leaves and twigs, roots were thoroughly washed by deionized water. Leaves, twigs and roots of each sampling were placed in a drying cabinet at $80^{\circ} \mathrm{C}$ for $48 \mathrm{~h}$ until a constant weight was reached. Samples were weighed, and ground then passed 200-mesh screen. Approximately $0.5( \pm 0.0001)$ g of material from each sample was accurately weighed into $50 \mathrm{~mL}$ ceramic crucible and carbonized on the heating furnace until the smoke dissipated. Then the ceramic crucible were transferred to the muffle furnace at $500^{\circ} \mathrm{C}$ for $8 \mathrm{~h}$. The resulting ash was dissolved in $10 \mathrm{~mL} \mathrm{HNO}_{3}(1: 1)$ and diluted to a final volume of $50 \mathrm{~mL}$ with deionized water and stored in polythene containers. Depending on detection limits, the Cd contents of the solutions were measured using the inductively coupled plasma optical emission spectrometry (ICP-AES).

\section{Statistical analysis}

Statistical analysis was performed based on STATISTICA (Statsoft, 1993). The data were analyzed through two-way and one-way analysis of variance (ANOVA) to determine the effect of treatments, species and parts of plants, and Duncan's multiple comparison tests were performed to determine the statistical significance of the differences among 
means of different Cd treatments, willow species and parts of plants.

\section{RESULTS AND DISCUSSION}

Accumulation of Cd in twig, leaf and root of Salix under different Cd supply levels

The Cd accumulation in twig, leaf and root in three Salix species treated with $\mathrm{Cd}(0.5 \mathrm{mg} / \mathrm{kg}$ to 60 $\mathrm{mg} / \mathrm{kg}$ ) is shown in Fig. 1 and 2. A two-way ANOVA showed that the amounts of $\mathrm{Cd}$ accumulation in the twig leaf and root were significantly affected by different species $(P<0.01)$, Cd treatment $(P<0.01)$ and interaction $(P<0.01)$ between species and $C d$ treatment (Table 1).

The contents of the $\mathrm{Cd}$ in the twigs (one-way ANOVA: $F_{5}=184.08, p<0.001$ for $S$. matsudana; $F_{5}=$ 256.51, $p<0.001$ for $S$. alba var. Tristis; $F_{5}=237.99, p$ $<0.001$ for $S$. babylonica), leaves $\left(F_{5}=485.77, p<\right.$ 0.001 for $S$. matsudana; $F_{5}=345.68, p<0.001$ for $S$. alba var. Tristis; $F_{5}=1192.34, p<0.001$ for $S$. babylonica) and roots $\left(F_{5}=940.26, p<0.001\right.$ for $S$. matsudana; $F_{5}=213.19, p<0.001$ for $S$. alba var. Tristis; $F_{5}=72.83, p<0.001$ for $S$. babylonica) were significantly different among different Cd treatments in all three Salix species. For all Salix species, the lowest $\mathrm{Cd}$ accumulation in twig, leaf and root always occurred in lowest Cd concentration treatments. Compared with the control, higher concentration Cd treatments $(6,25,60 \mathrm{mg} / \mathrm{kg})$ significantly promoted Cd uptake of the twig, leaf and root for all species (Fig. 1).

For S. matsudana, the amounts of Cd accumulation in twig and leaf dramatically and significantly increased with the addition of $\mathrm{Cd}$ concentration, however, under the highest Cd concentration (60 mg/ $\mathrm{kg}$ ), the amount of $\mathrm{Cd}$ accumulation in root was significantly lower than that of $25 \mathrm{mg} / \mathrm{kg}$ Cd treatment, and higher than other Cd treatments. The amounts of Cd accumulation in twig, leaf and root of $S$. alba var. Tristis and in twig of S. babylonica under the highest $\mathrm{Cd}$ concentration $(60 \mathrm{mg} / \mathrm{kg})$ were significantly lower than that of $25 \mathrm{mg} / \mathrm{kg} \mathrm{Cd}$ treatment and higher than that of the other $\mathrm{Cd}$ treatments. The amount of Cd accumulation in all three parts of $S$. alba var. Tristis under the $6 \mathrm{mg} / \mathrm{kg}$ Cd treatment was significantly higher than that of other lower Cd concentration treatments and the control. The higher Cd concentration treatments (25, $60 \mathrm{mg} / \mathrm{kg})$ significantly promoted the Cd accumulation in root and leaf of babylonica, there was no significant difference for the amounts of $\mathrm{Cd}$ accumulation between the $25 \mathrm{mg} / \mathrm{kg}$ and 60 $\mathrm{mg} / \mathrm{kg} \mathrm{Cd}$ treatments, among the control and the lower concentration treatments $(0.5,2 \mathrm{mg} / \mathrm{kg})$. The amounts of Cd accumulation in root and leaf of $S$. babylonica under the $6 \mathrm{mg} / \mathrm{kg} \mathrm{Cd}$ treatment were significantly higher than that of other lower $\mathrm{Cd}$ concentration treatments and the control and lower than that of the 25 and $60 \mathrm{mg} / \mathrm{kg} \mathrm{Cd}$ treatments (Fig. 1). There were the significant correlations between the amounts of Cd accumulation in twig, leaf and root and Cd concentration for all three Salix species (Table 2).

Difference of Cd accumulation in twig, leaf and root among Salix species

The contents of the $\mathrm{Cd}$ in the twigs (one-way ANOVA: $F_{2}=4.09, p=0.0383$ for the control; $F_{2}=$ 18.63, $p<0.001$ for the $0.5 \mathrm{mg} / \mathrm{kg}$ Cd treatment; $F_{2}=$ 18.42, $p<0.001$ for the $2 \mathrm{mg} / \mathrm{kg}$ Cd treatment; $F_{2}=$ 39.37, $p<0.001$ for the $6 \mathrm{mg} / \mathrm{kg}$ Cd treatment; $F_{2}=$ $33.79, p<0.001$ for the $25 \mathrm{mg} / \mathrm{kg}$ Cd treatment; $F_{2}=$ 163.79, $p<0.001$ for the $60 \mathrm{mg} / \mathrm{kg}$ Cd treatment) and leaves $\left(F_{2}=9.86, p=0.0019\right.$ for the control; $F_{2}=13.66$,

Table 1: Analysis of variance for the effects of different species, Cd treatments, and their interaction on accumulation of the leaves, twigs and roots for three Salix species

\begin{tabular}{|c|c|c|c|c|}
\hline Part of plant & Source of variation & $\mathrm{df}$ & $F$-value & $P$ \\
\hline Leaves & $\begin{array}{l}\text { Cd treatment } \\
\text { species } \\
\text { Cd treatment } \times \text { species }\end{array}$ & $\begin{array}{r}5 \\
2 \\
10\end{array}$ & $\begin{array}{r}1600.74 \\
556.60 \\
539.81\end{array}$ & $\begin{array}{l}<0.001 \\
0.0018 \\
<0.001\end{array}$ \\
\hline Twigs & $\begin{array}{l}\text { Cd treatment } \\
\text { species } \\
\text { Cd treatment } \times \text { species }\end{array}$ & $\begin{array}{r}5 \\
2 \\
10\end{array}$ & $\begin{array}{r}1423.23 \\
317.30 \\
300.98\end{array}$ & $\begin{array}{l}<0.001 \\
0.0031 \\
<0.001\end{array}$ \\
\hline Roots & $\begin{array}{l}\text { Cd treatment } \\
\text { species } \\
\text { Cd treatment } \times \text { species }\end{array}$ & $\begin{array}{r}5 \\
2 \\
10\end{array}$ & $\begin{array}{r}1266.91 \\
440.35 \\
604.39\end{array}$ & $\begin{array}{l}<0.001 \\
0.0023 \\
<0.001\end{array}$ \\
\hline
\end{tabular}


$p=0.004$ for the $0.5 \mathrm{mg} / \mathrm{kg}$ Cd treatment; $F_{2}=11.81$, $p=0.008$ for the $2 \mathrm{mg} / \mathrm{kg}$ Cd treatment; $F_{2}=86.32$, $p<0.001$ for the $6 \mathrm{mg} / \mathrm{kg} \mathrm{Cd}$ treatment; $F_{2}=51.97$, $p<0.001$ for the $25 \mathrm{mg} / \mathrm{kg}$ Cd treatment; $F_{2}=183.29$, $p<0.001$ for the $60 \mathrm{mg} / \mathrm{kg} \mathrm{Cd}$ treatment) were significantly different among three Salix species under all Cd treatments. There were significantly difference for the amount of Cd accumulation in the roots among three Salix species under $0.5 \mathrm{mg} / \mathrm{kg}\left(F_{2}\right.$ $=12.73, p<0.001), 2 \mathrm{mg} / \mathrm{kg}\left(F_{2}=4.48, p=0.0238\right), 6 \mathrm{mg} /$ $\mathrm{kg}\left(F_{2}=229.37, p<0.001\right)$ and $25 \mathrm{mg} / \mathrm{kg}\left(F_{2}=47.38\right.$, $p<0.001$ ), but not for the control and the $60 \mathrm{mg} / \mathrm{kg} \mathrm{Cd}$ treatment.

S. matsudana and S. alba var. Tristis did not perform significant difference in the amounts of $\mathrm{Cd}$ accumulation in the twigs and leaves at $0.5 \mathrm{mg} / \mathrm{kg}$ treatment, in the roots at $6 \mathrm{mg} / \mathrm{kg}$ treatment, in the leaves at 2 and $25 \mathrm{mg} / \mathrm{kg}$ treatment, were significantly higher than S. babylonica. S. matsudana always performed the biggest amounts of $\mathrm{Cd}$ accumulation in twig the 2, 6 and $25 \mathrm{mg} / \mathrm{kg}$ treatments, in root at $25 \mathrm{mg} / \mathrm{kg}$ treatment, and $S$. babylonica performed the poorest accumulation ability significantly. The leaves at the 6 and $60 \mathrm{mg} / \mathrm{kg}$ and the twigs at $60 \mathrm{mg} / \mathrm{kg} \mathrm{Cd}$ treatments of $S$. matsudana always accumulated the most amount of Cd than the other two species which did not performed significant difference in the amounts of $\mathrm{Cd}$ accumulation (Fig. 2).

Accumulation of Cd in different part of three Salix species

The amounts of Cd accumulation under the control $\left(F_{2}=62.32, p<0.001\right.$ for $S$. matsudana; $F_{2}=17.08, p<$ 0.001 for $S$. alba var. Tristis; $F_{2}=53.92, p<0.001$ for $S$. babylonicas ), the $0.5 \mathrm{mg} / \mathrm{kg}$ (one-way ANOVA: $F_{2}=$ 8.48, $p=0.0034$ for $S$. matsudana; $F_{2}=9.23, p=0.0024$ for S. alba var. Tristis; $F_{2}=19.17, p<0.001$ for $S$. babylonicas), $2 \mathrm{mg} / \mathrm{kg}$ ( $F_{2}=28.52, p<0.001$ for $S$. matsudana; $F_{2}=68.17, p<0.001$ for $S$. alba var. Tristis; $F_{2}=28.47, p<0.001$ for $S$. babylonicas $), 6 \mathrm{mg} / \mathrm{kg}\left(F_{2}=\right.$ 24.68, $p<0.001$ for $S$. matsudana; $F_{2}=2.72, p=0.0984$ for S. alba var. Tristis; $F_{2}=81.67, p<0.001$ for $S$. babylonicas), $25 \mathrm{mg} / \mathrm{kg}\left(F_{2}=28.42, p<0.001\right.$ for $S$. matsudana; $F_{2}=74.55, p<0.001$ for $S$. alba var. Tristis; $F_{2}=63.73, p<0.001$ for $S$. babylonicas) and $60 \mathrm{mg} / \mathrm{kg}$ $\left(F_{2}=261.38, p<0.001\right.$ for $S$. matsudana; $F_{2}=37.08, p<$ 0.001 for $S$. alba var. Tristis; $F_{2}=59.99, p<0.001$ for $S$. babylonicas) Cd treatment were significantly different among three parts of Salix species, but no for S. alba var. Tristis at the $60 \mathrm{mg} / \mathrm{kg} \mathrm{Cd}$ treatment.

At the control, the amounts of Cd accumulation in the twigs and leaves for all three species were not significantly different, but significantly higher than the root. At the $0.5 \mathrm{mg} / \mathrm{kg} \mathrm{Cd}$ treatment, there are not significantly difference in the amounts of $\mathrm{Cd}$ accumulation between the twigs and leaves for $S$. matsudana and S. alba var. Tristis, and the amounts of Cd accumulation in aboveround parts were significantly higher than underground part for these two species, for $S$. babylonicas, the amounts of $\mathrm{Cd}$ accumulation in the leaves were significantly higher than the twigs and roots which did not performed significant difference each other. At the 2, 6 and $25 \mathrm{mg} /$ $\mathrm{kg}$ Cd treatments, the amounts of Cd accumulation in the twigs and leaves for $S$. matsudana were not significantly different, but significantly higher than that of the root, for S. babylonicas, the amounts of $\mathrm{Cd}$ accumulation in the twigs were significantly higher than that of the roots and lower than that of the leaves. The amounts of $\mathrm{Cd}$ accumulation in the twigs under 2 and $25 \mathrm{mg} / \mathrm{kg}$ Cd treatments for S. alba var. Tristis, and $60 \mathrm{mg} / \mathrm{kg} \mathrm{Cd}$ treatment for S. babylonicas

Table 2: Correlations of Cd concentration to the amount of $\mathrm{Cd}$ accumulation in leaves, twigs and roots

\begin{tabular}{|c|c|c|c|c|c|}
\hline Part of plant & Species & Linear model & $\mathrm{R}^{2}$ & $F$-value & $P$ \\
\hline \multirow{2}{*}{ Leaves } & S. matsudana & $y=-9813.07+96.44 x$ & 0.8965 & 304.1300 & $<0.001$ \\
\hline & S. babylonica & $y=-4934.21+48.49 x$ & 0.8341 & 177.0025 & $<0.001$ \\
\hline \multirow{3}{*}{ Twigs } & S. matsudana & $y=-8257.89+81.20 x$ & 0.8643 & 223.9807 & $<0.001$ \\
\hline & S. alba var. Tristis & $y=-4085.65+40.27 x$ & 0.6197 & 58.0378 & $<0.001$ \\
\hline & S. babylonica & $y=-3434.73+33.77 x$ & 0.7709 & 118.7699 & $<0.001$ \\
\hline \multirow[t]{2}{*}{ Roots } & S. alba var. Tristis & $y=-2918.02+28.75 x$ & 0.7765 & 122.5741 & $<0.001$ \\
\hline & S. babylonica & $y=-2263.78+22.25 x$ & 0.7627 & 113.5081 & $<0.001$ \\
\hline
\end{tabular}


and S. matsudana, were significantly higher than that of the roots and lower than that of the leaves. The amount of $\mathrm{Cd}$ accumulation in the leaves under $60 \mathrm{mg} /$
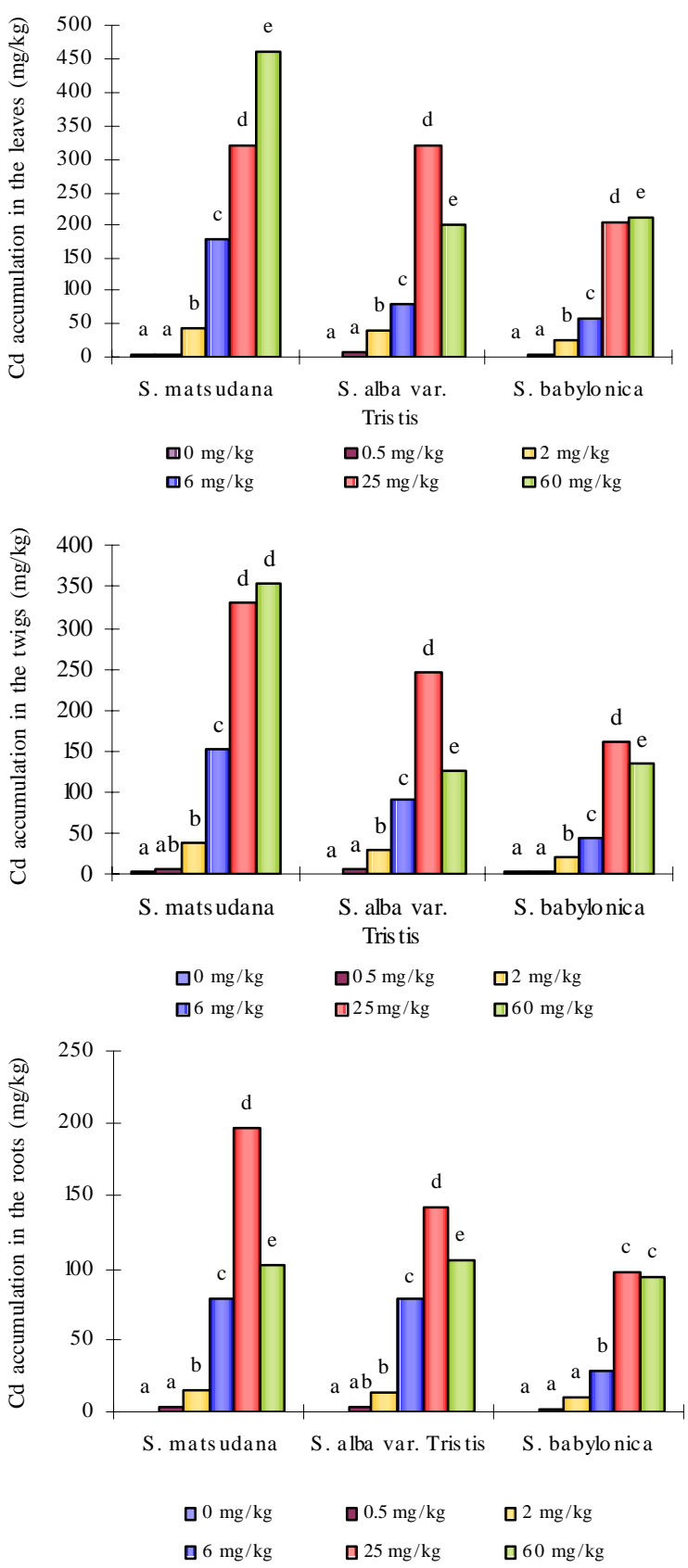

Fig. 1: Accumulation difference of six different Cd treatments in twig, leaf and root among three Salix species. Values with the same letters are not significantly different among treatments kg Cd treatment was significantly higher than that of the twigs and roots which did not performed significant difference each other (Fig. 3).
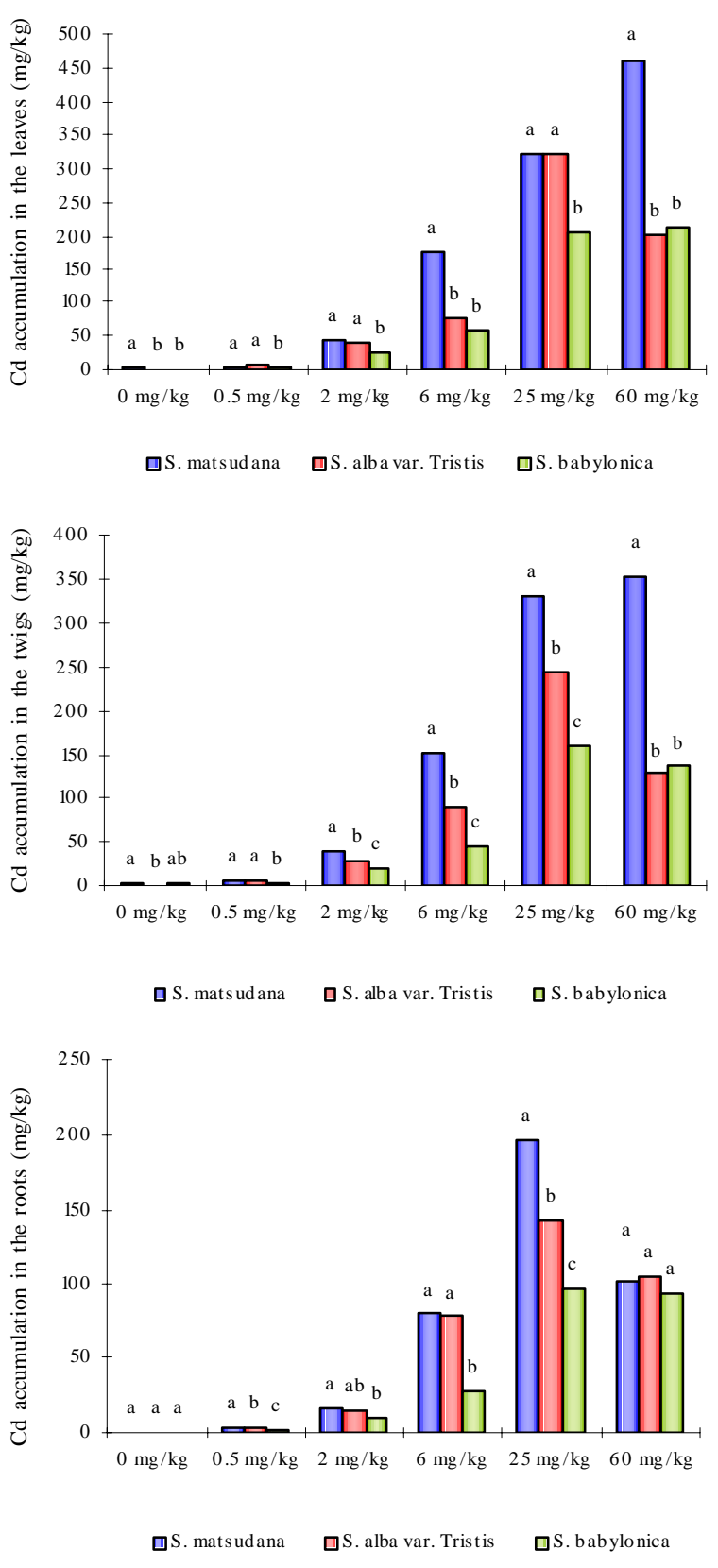

Fig. 2: Accumulation difference of three Salix species in twig, leaf and root among six different Cd treatments. Values with the same letters are not significantly different among treatments 
T. Ling et al.
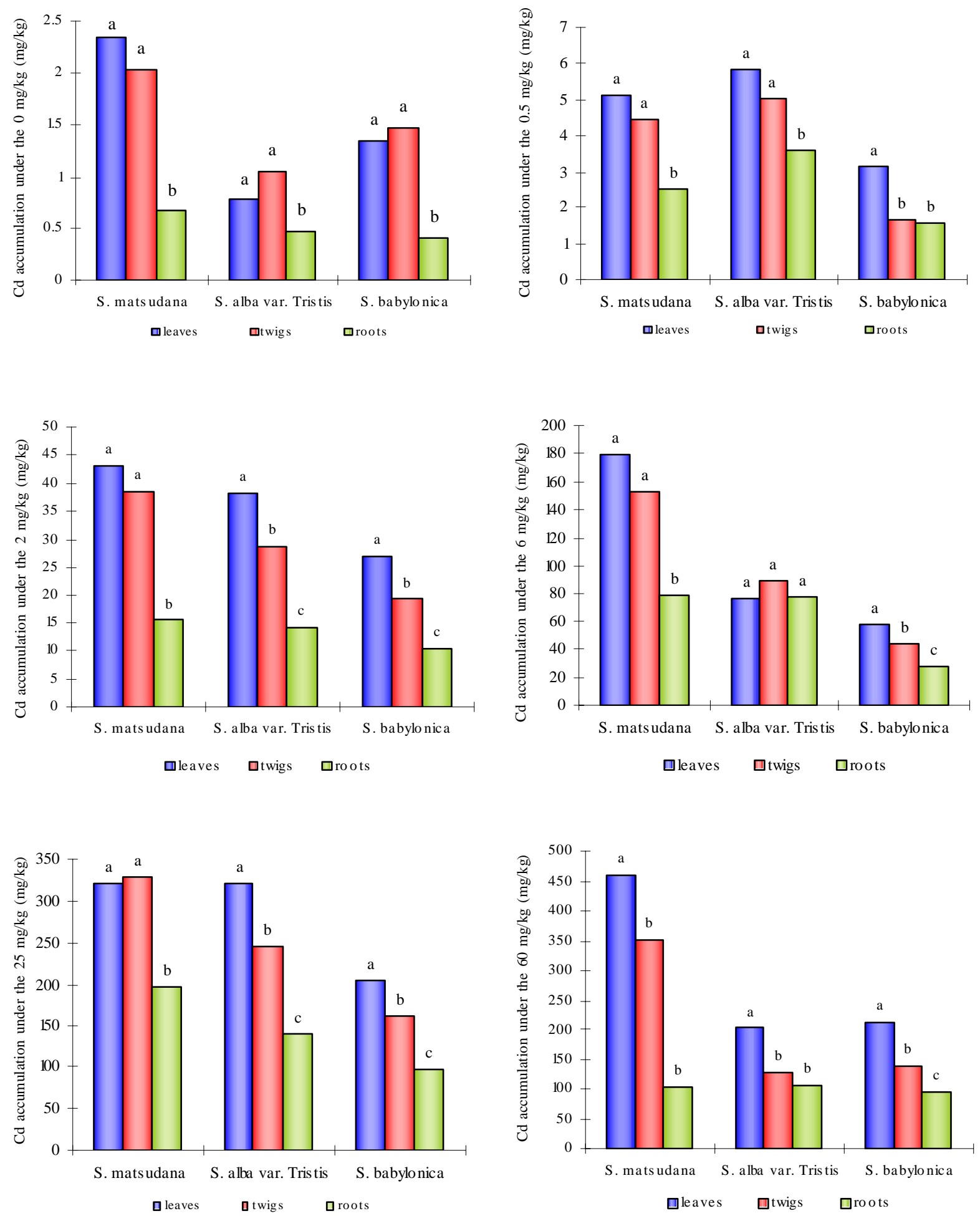

Fig. 3: Accumulation difference of three parts for three Salix under six different Cd treatments. Values with the same letters are not significantly different among treatments 


\section{CONCLUSION}

The Cd accumulation in the leave, twigs and root of the tested Salix species always increased with the addition of Cd supply, only at the highest Cd supply conditions, the $\mathrm{Cd}$ accumulation in the twigs and root for S. alba var. Tristis and S. babylonicas, in the leaves for $S$. alba var. Tristis performed significant decrease. For all tested Salix species, Cd accumulated by the leaves, twigs and roots linearly increased with increasing Cd supply levels, peaked at the Cd level of $60 \mathrm{mg} / \mathrm{kg}$ in twigs and leaves of $S$. matsudana and 25 $\mathrm{mg} / \mathrm{kg}$ for $S$. alba var. Tristis which then decreased with further increasing external Cd level. For $S$. babylonica, the maximum amount of Cd taken up by the twigs and roots were as high as 161.62 and 97.64 $\mathrm{mg} / \mathrm{kg}$, respectively, grown at the Cd level of $25 \mathrm{mg} /$ $\mathrm{kg}$, and the highest amount of $\mathrm{Cd}$ accumulation in the leaves performed at the treatment of $60 \mathrm{mg} / \mathrm{kg}$.

The result of this study indicated that Salix has an excellent potential for $\mathrm{Cd}$ phytoremediation because of its high accumulation ability. By comparison of individual aboveground parts of plants, Cd was intensively accumulated in leaves than in twigs. Cd was not retained in roots and was transferred to aboveground plant tissues in all tested species.

\section{ACKNOWLEDGEMENTS}

This research was supported by Program for Changjiang Scholars and Innovative Research Team in University (IRT0966) and by the National Natural Science Foundation (No. 30970490).

\section{REFERENCES}

Atafar, Z.; Mesdaghinia, A.; Nouri, J.; Homaee, M.; Yunesian, M., (2010). Effect of fertilizer application on soil heavy metal concentration. Environ. Monitor. Assess., 160 (1-4), 83-89 ( 7 pages).

Ayari, F.; Hamdi, H.; Jedidi, N.; Gharbi, N.; Kossai, R., (2010). Heavy metal distribution in soil and plant in municipal solid waste compost amended plots. Int. J. Environ. Sci. Tech., 7 (3), 465-472 (8 pages).

Blaylock, M. J.; Huang, J. W., (2000). Phytoextraction of metals. In: Raskin, I. and Ensley, B. D. (Eds.), Phytoremediation of toxic metals: using plants to cleanup the environment. New York, John Wiley and Sons, Inc.

Cunningham, S. D.; Owen, D. W., (1996). Promises and prospects of phytoremediation. Plant Physiol., 110 (3), 715-719 (5 pages)

Das, P.; Samantaray, S.; Rout, G. R., (1997). Studies on cadmium toxicity in plants: A review. Environ. Pollut., 98 (1), 2936 (8 pages).
Dickinson, N. M., (2000). Strategies for sustainable woodland on contaminated soils. Chemosphere, 41(1-2), 259-263 (5 pages).

Dobaradaran, S.; Mahvi, A. H.; Dehdashti, S., (2008a). Fluoride content of bottled drinking water available in Iran. Fluoride, 41 (1), 93-94 (2 pages).

Dobaradaran, S.; Mahvi, A. H.; Dehdashti, S.; Abadi, D. R. V.; Tehran, I., (2008b). Drinking water fluoride and child dental caries in Dashtestan, Iran. Fluoride, 41 (3), 220-226 ( 7 pages)

Eriksson, J.; Ledin, S., (1999). Changes in phytoavailability and concentration of cadmium in soil following long term Salix cropping. Water, Air Soil Pollut., 15 (1-2), 171-184 (14 pages).

Goyal, P.; Sharma, P.; Srivastava, S.; Srivastava, M. M., (2008). Saraca indica leaf powder for decontamination of $\mathrm{Pb}$ : removal, recovery, adsorbent characterization and equilibrium modeling. Int. J. Environ. Sci. Tech. 5 (1), 2734 (8 pages).

Greger, M.; Landdberg, T., (1999). Use of willow in phytoextraction. Int. J. Phytoremediat., 1 (2), 115-123 (9 pages)

Jamal, S. N.; Iqbal, M. Z.; Athar, M., (2006). Phytotoxic effect of aluminum and chromium on the germination and early growth of wheat (Triticum aestivum) varieties Anmol and Kiran. Int. J. Environ. Sci. Tech., 3 (4), 411-416 (6 pages).

Jun, R.; Ling, T.; Guanghua, Z., (2009). Effects of chromium on seed germination, root elongation and coleoptile growth in six pulses. Int. J. Environ. Sci. Tech., 6 (4), 571-578 (8 pages).

Lasat, M. M., (2002). Phytoextraction of toxic metals: A review of biological mechanisms. J. Environ. Qual., 31 (1), 109-120 (12 pages).

Ledin, S., (1998). Environmental consequences when growing short rotation forest in Sweden. Biomass and Bioenergy, 15 (1), 49-55 (7 pages).

Lee, I.; Baek, K.; Kim, H.; Kim, S.; Kim, J.; Kwon, Y.; Chang, Y.; Bae, B., (2007). Phytoremediation of soil cocontaminated with heavy metals and TNT using four plant species. J. Environ. Sci. Health Part A., 42 (13), 20392045 (7 pages).

Mahmood, S.; Hussain, A.; Saeed, Z.; Athar, M., (2005). Germination and seedling growth of corn (Zea mays l.) under varying levels of copper and zinc. Int. J. Environ. Sci. Tech., 2 (3), 269-274 (6 pages).

Maria, N.; Utmazian, D. S.; Wenzel, W. W., (2007). Cadmium and zinc accumulation in willow and poplar species grown on polluted soils. J. Plant Nutr. Soil Sci., 170 (2), 265-272 (8 pages).

Meers, E.; Hopgood, M.; Lesage, E.; Vervaeke, P.; Tack, F. M. G.; Verloo, M. G., (2004). Enhanced phytoextraction: In search of EDTA alternatives. Int. J. Phytoremediat., 6 (2), 95-109 (15 pages).

Nabulo, G.; Oryem Origa, H.; Nasinyama, G. W.; Cole, D., (2008). Assessment of $\mathrm{Zn}, \mathrm{Cu}, \mathrm{Pb}$ and $\mathrm{Ni}$ contamination in wetland soils and plants in the lake basin. Int. J. Environ. Sci. Tech., 5 (1), 65-74 (10 pages).

Nouri, J.; Khorasani, N.; Lorestani, B.;Yousefi, N.; Hassani, A.H.; Karami, M., (2009). Accumulation of heavy metals in soil and uptake by plant species with phytoremediation potential. Environ. Earth Sci. 59 (2), 315-323 (9 pages). 
Perez-Sirvent, C.; Martinez-Sanchez, M. J.; Garcia-Lorenzo, M. L.; Bech, J., (2008). Uptake of Cd and Pb by natural vegetation in soils polluted by mining activities. Fresenius Environ. Bull., 17 (10b), 1666-1671 (6 pages).

Pulford, I. D.; Watson, C., (2003). Phytoremediation of heavy metal-contaminated land by trees - A review. Environ. Int., 29 (4), 529-540 (12 pages).

Punshon, T.; Dickinson, N. M., (1996). The potential of Salix clones for bioremediating metal polluted soil. Glimmerveen, I., (Ed.). Heavy metals and trees. Proceedings of a discussion meeting, Glasgow, Edinburgh: Institute of Chartered Foresters.

Reeves, R. D.; Baker, A. J. M., (2000). Metal accumulation in plants. Ensley B. D.; Raskin, I., (Eds.). Phytoremediation of toxic metals: Using plants to clean up the environment.
John Wiley and Sons, New York, USA.

Shrestha, R.; Fischer, R.; Sillanpaa, M., (2007). Investigations on different positions of electrodes and their effects on the distribution of $\mathrm{Cr}$ at the water sediment interface. Int. J. Environ. Sci. Tech., 4 (4), 413-420 (8 pages).

Statsoft, Inc., (1993). STATISTICA for Windows Release 4.5

Vyslouzilova, M.; Tlustos, P.; Szakova, J., (2003). Cadmium and zinc phytoextraction potential of seven clones of Salix spp. Plants on heavy metal contaminated soil. Plant, Soil Environ., 49 (12), 542-547 (6 pages).

Zacchini, M.; Pietrini, F.; Mugnozza, G. S.; Pietrosanti, V. L.; Massacci, A., (2009). Metal tolerance, accumulation and translocation in poplar and willow clones treated with cadmium in hydroponics. Water Air Soil Pollut., 197 (1-4), 23-34 (12 pages).

\section{AUTHOR (S) BIOSKETCHES}

Ling, T., Ph.D., Professor, School of Environmental and Municipal Engineering and Institute of Environmental Ecology, Lanzhou Jiaotong University, Lanzhou, China. Email: taoling@mail.lzjtu.cn

Jun, R., Ph.D., Professor, School of Environmental and Municipal Engineering and Institute of Environmental Ecology, Lanzhou Jiaotong

University, Lanzhou, China. Email: renjun@mail.lzjtu.cn

Fangke, Y., M.Sc., School of Environmental and Municipal Engineering and Institute of Environmental Ecology, Lanzhou Jiaotong University, Lanzhou, China. Email: yangliu@mail.lzjtu.cn

How to cite this article: (Harvard style)

Ling, T.; Jun, R.; Fangke, Y., (2011). Effect of cadmium supply levels to cadmium accumulation by Salix. Int. J. Environ. Sci. Tech., 8 (3), 493-500. 